\title{
Upper Ordovician graptolites from the Cape Phillips Formation, Canadian Arctic Islands
}

MICHAEL J. MELCHIN

\begin{abstract}
Melchin, M. J., Upper Ordovician graptolites from the Cape Phillips Formation Canadian Arctic Islands. Bull. geol. Soc. Denmark. vol. 35 pp. 191-202. Copenhagen, July 1st, 1987.

https://doi.org/10.37570/bgsd-1986-35-20

Ashgill age graptolites have been collected from seven sections of the Cape Phillips Formation across most of its outcrop belt. The earliest graptolite zone recognisable is that of Orthograptus fastigatus. It is correla-ted with the Dicellograptus ornatus 'Zone of the northern Canadian Cordilllera and the Dicellograptus complexus Subzone of the Dicellograptus anceps Zone of Great Britain although no dicellograptids have been found at any of the present sections. The overlying zone is that of Paraorthograptus pacificus, an ea-sily recognisable zone around much of the world.

Graptolites of the Climacograptus extraordinarius and Glyptograptus persculptus zones appear to be en-tirely absent from this formation. This is attributed to the Late Ordovician glaciation which has induced regression and submarine erosion in many areas worldwide.

The earliest recognisable Silurian zone varies from section to section due to buried or barren intervals and/or hiatuses of varying length. The Parakidograptus acuminatus Zone has been recognised at only one section. At the others, the Atavograptus atavus, the Lagarograptus acinaces-Coronograptus gregarius, the Monograptus convolutus or the Monograptus spiralis Zone (s.l.) are the earliest recognisable Silurian fau-nas.

Relatively low faunal diversities in the Ashgill and lowest Llandovery portion of the section and the total lack of dicellograptids are interpreted to be due to relatively shallow water, outer shelf or carbonate ramp depositional environment.
\end{abstract}

M. J. Melchin, Department of Geology, The University of Western Ontario, London, Ontario, Canada, N6A 5B7, August 20, 1986.

\section{Introduction}

The Cape Phillips Formation occurs in the Queen Elizabeth Island group of the Canadian Arctic Archipelago. The formation was originally defined and described by Thorsteinsson (1958) on Cornwallis Island and has since been mapped from central Melville Island in the west to central Ellesmere Island in the northeast (figure 1). The Cape Phillips ranges in age from late Ordovician to Early Devonian across much of its outcrop area, although in some parts of the Bathurst Island Group (Kerr 1974; Mayr 1980) and Ellesmere Island (Kerr 1976; Tretting 1979) its age range is more restricted.

Probable Ordovician and Silurian graptolites were first reported from Ellesmere Island by Troelsen (1950) from what he called the Thorup Fjord Limestone, now considered the lower portion of the Cape Phillips Formation (Tozer 1963). Thorsteinsson and Fortier (1954) first reported the well preserved graptolite faunas of Late Ordovician and Silurian age on Cornwallis and
Little Cornwallis islands and these faunas were listed in some detail by Thorsteinsson (1958). In the latter report twenty-two zones were recognised from Late Ordovician to Late Silurian in age. Two of these zones were considered Late Ordovician and were named for Orthograptus n.sp. A and Climacograptus latus Elles and Wood. They were tentatively correlated with complanatus and anceps zones of Great Britain respectively. In association with these, a diverse cephalopod fauna has been reported (Sweet and Miller 1957) as well as the trilobite Pseudogygites latimarginatus which has been subsequently redescribed by Ludvigsen (1979) as P. arcticus. Orthograptus n.sp. C and Climacograptus supernus Elles and Wood $(=C$. longispinus supernus $)$ were also found in association with $C$. latus.

While the presence of $C$. latus and $C$. l. supernus provided a reliable correlation with the anceps Zone, the zone of $O$. n.sp. A could not be accurately dated except as Late Ordovician based on the cephalopod and trilobite faunas.

Aspects of these Ordovician faunas have since 


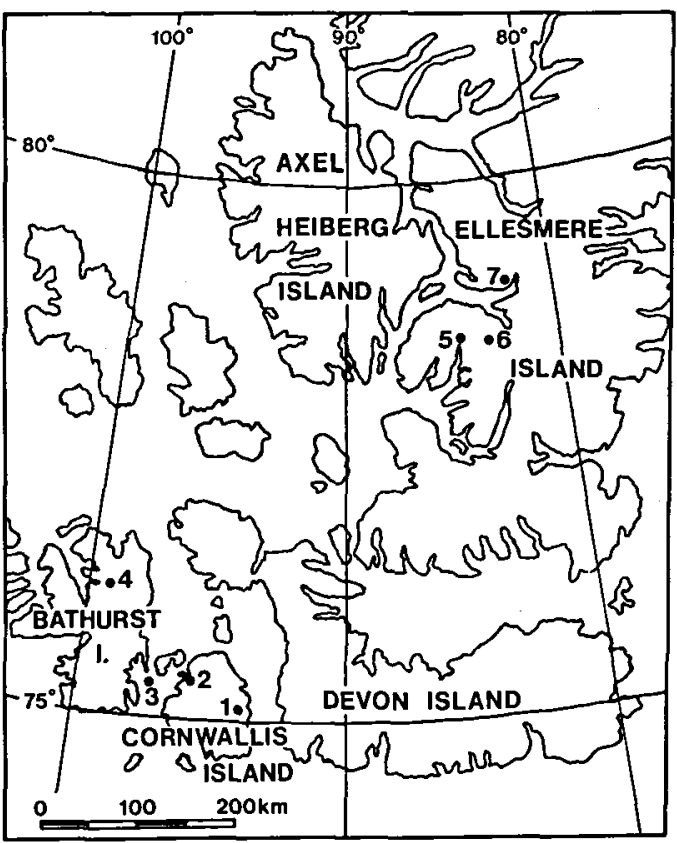

Fig. 1. Map of the east-central portion of the Canadian Arctic Islands showing Ordovician graptolite localities: 1. Snowblind Creek, $75^{\circ} 11^{\prime} \mathrm{N}, 93^{\circ} 47^{\prime} \mathrm{W} ; 2$. Rookery Creek, $75^{\circ} 22^{\prime} \mathrm{N}$, $95^{\circ} 46^{\prime} \mathrm{W} ; 3$. Truro Island, $75^{\circ} 18^{\prime} \mathrm{N}, 98^{\circ} 08^{\prime} \mathrm{W} ; 4$. Twilight Creek, $76^{\circ} 10^{\prime} \mathrm{N}, 99^{\circ} 10^{\prime} \mathrm{W}$; 5. Trold Fiord, $78^{\circ} 36^{\prime} \mathrm{N}, 8^{\circ} 37^{\prime} \mathrm{W} ; 6$. Huff Ridge, $78^{\circ} 34^{\prime} \mathrm{N}, 83^{\circ} 32^{\prime} \mathrm{W} ; 7$. Irene Bay, $79^{\circ} 04^{\prime} \mathrm{N}, 82^{\circ} 15^{\prime} \mathrm{W}$.

been found in the Bathurst Island Group (Thorsteinsson and Glenister 1963; Kerr 1974) and on Ellesmere Island (Tozer 1963; Kerr 1976). In addition, Riva (in Ludvigsen 1979) found a species of Glyptograptus with a long virgella and basal spines (possibly Orthograptus thorsteinssoni n.sp. of this report) and another species of Glyptograptus or "Pseudoclimacograptus" which he considered to be post-pygmaeus Zone.

The earliest Silurian graptolite zone reported by Thorsteinsson (1958) was that of Monograptus cyphus Lapworth.

While several other papers have involved description or reports of Cape Phillips graptolites (i.e. Thorsteinsson 1955; Lenz 1974a, b, 1978; Jackson et al. 1978), none has been devoted to the description of Ordovician or earliest Silurian faunas. Chen and Lenz (1984) listed some of the Ordovician graptolites collected as part of the present study.

During the summers of 1983 and 1984, Ashgill graptolites were collected from sections across much of the outcrop belt (figure 1). Section 1 at
Snowblind Creek occurs on the line of the Cape Phillips-Allen Bay facies change (Thorsteinsson 1958) and the Ordovician and lowest Silurian parts of the section are largely dolomites. One sample near the base, however, has yeilded two specimens of $O$. fastigatus Davies. At section 2, Rookery Creek, the Ordovician and lowest Silurian parts of the section are mostly covered, but $O$. fastigatus and $O$. thorsteinsson $i$ were collected near the base of the formation. At both of these sections the earliest recognisable Silurian graptolite faunas are of approximately convolutus Zone age. The stratigraphy and graptolite faunas of the remaining five sections are illustrated in figure 2 .

Identifications of the post-atavus Zone graptolites and zonal designations are tentative.

\section{Stratigraphy}

The Cape Phillips Formation is divided into three members, A, B and C. Member A, which ranges in age from Ashgill to Middle Llandovery, varies in thickness from 50 to about $156 \mathrm{~m}$. It consists of interbedded carbonates, argillaceous carbonates and shales. The carbonates, for the most part, consist of thinly laminated, argillaceous limestones or weakly bioturbated limestones. At the base of the formation is a persistently developed, medium to thickly bedded carbonate unit 10 to 15 $m$ thick. This unit may be partially or completely dolomitized but where original structures are preserved, at bioturbated lime wackestone is the lithology.

Toward the top of this member the occurrence of bioturbated limestones decreases and laminated limestones and shales dominate with some chert present. The laminated limestones commonly show very fine continuous or discontinuous lenticular bedding, while others show plane laminar layering.

While most workers generally refer to the Cape Phillips as representing "slope" or "basinal" facies, the evidence indicates that, in the Ordovician part of the section, water depths were probably those of deep shelf rather than basinal. Ludvigsen (1979) has examined Pseudogygitesbearing dark limestone/shale sequences in eastern and arctic Canada including the lowest Cape Phillips. He suggested that the transition from light-coloured, bioturbated limestones to dark, 


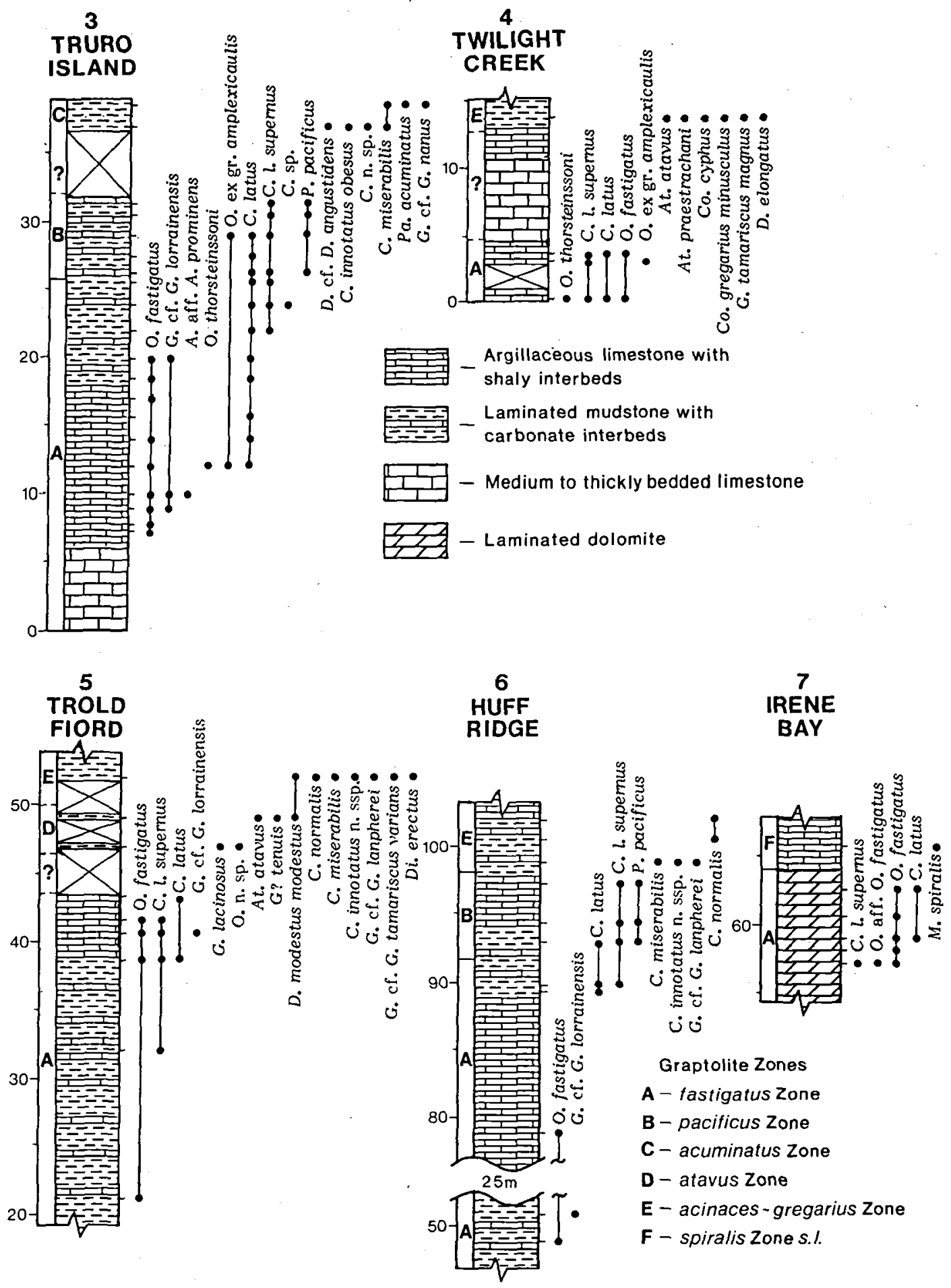

Fig. 2. Lithology and distribution of graptolite faunas of main sampled sections. Measurements are in metres above base. For description of sections 1 and 2 , see text. 
argillaceous, laminated limestones and shales was due not necessarily to increasing water depths but to the establishment of a permanent thermocline over the shelf areas. This has resulted in a drastic reduction of the behthic faunas and preservation of abundant graptolites and other organic material.

Further evidence of relatively shallow depositional depths can be seen in the very gradual nature of the lateral facies change seen during this interval. The Allen Bay Formation is the shallow water carbonate facies equivalent of the lower part of the Cape Phillips. During the Ordovician, patch reefs have been recorded in the Allen Bay but are separated from the Cape Phillips beds by a lateral transition of shallow to deeper shelf carbonates (Mayr 1974; Mirza 1976; Sodero and Hobson 1979). The lack of development of gravity flows (except, possibly, very fine-grained turbidites) or any other evidence of increased slope or shelf break suggests deposition of the lowest Cape Phillips on the deeper portion of a shelf of carbonate ramp (Read 1982) rather than a deep basin. Increased shelf-to-basin relief appears to have begun to develop from Middle Llandovery time onward (Melchin and Lenz 1984).

\section{Graptolite Biostratigraphy}

The lowest graptolite-bearing beds at all of the sampled sections have yielded Orthograptus fastigatus, often in great abundance. It commonly occurs in conjunction with Pseudogygites arcticus and nautiloid cephalopods. Orthograptus fastiga$t u s$ is probably synonymous with $O$. n.sp. A of Thorsteinsson (1958) based on its abundance and co-occurrence with this distinctive "Arctic Ordovician fauna".

Orthograptus fastigatus is found to be restricted to the complexus Subzone of the anceps Zone in Great Britain (Williams 1982). The lower end of its age range in the present sections has not been dated accurately by any independent means but the upper end of its range is consistently below the first occurrence of $P$. pacificus so it is concluded that this interval, here termed the fastigatus Zone, is correlative with the complexus Subzone. It may also be equivalent to the ornatus Zone of the Northern Canadian Cordillera (Lenz and McCracken 1982).
While Thorsteinsson did not report any other graptolite taxa co-occurring with $O$. fastigatus, several other species have been found with it at most of the present sections. Glyptograptus cf. $G$. lorrainensis (Ruedemann) and Amplexograptus aff. A. prominens Barrass although uncommon here, are the only taxa from this unit closely resembling the faunas of the platform areas of central and eastern Canada (Riva 1969; Jackson 1973) and suggest a possible correlation with the inuiti Zone of that region (Bergström and Mitchell 1986). Orthograptus thorsteinssoni and Climacograptus sp. are also restricted to the fastigatus Zone and are relatively uncommon.

Climacograptus latus and C. longispinus supernus, although found by Thorsteinsson (1958) to overlie samples yielding $O$. fastigatus, co-occur with the latter at most of the section sampled. Their ranges extend beyond the fastigatus Zone, however, to the highest Ordovician beds found, the pacificus Zone.

Paraorthograptus pacificus (Ruedemann), a distinctive index fossil in the upper Ashgill of many parts of the world, has been found at two of the sampled sections (sections 3 and 6) together with $C$. latus, and $C$. $l$. supernus. At sections 2 and 5 this interval is covered while at sections 1 and 4 it is represented by unfossiliferous strata. The pacificus Zone appears to be entirely absent at section 7 .

Orthograptus ex. gr. amplexicaulis occurs rarely in the fastigatus and pacificus zones.

As in the Northern Cordillera (Lenz and McCracken 1982) evidence of the extraordinarius Zone is entirely lacking, as is any evidence of the persculptus Zone.

\section{The Ordovician-Silurian Boundary}

The actual Ordovician-Silurian boundary beds are only exposed at three of the sampled sections, sections 4, 6 and 7 (figure 2).

At section 3, a $5.0 \mathrm{~m}$ buried interval is followed by two exposed beds which have yielded a fauna assignable to the acuminatus Zone, including Parakidograptus acuminatus (Nicholson) itself.

The boundary interval at section 4 is occupied by $10.0 \mathrm{~m}$ of strata, mostly bioturbated limestones with a sparse, poorly preserved shelly fauna, apparently lacking in graptolites. The ol- 
dest identifiable Silurian graptolites can be assigned to an undivided acinaces-gregarius Zone, correlative, at least in part, with these zones in the Northern Cordillera (Lenz 1982) and the $c y$. phus Zone of Alaska (Churkin and Carter 1970).

At section 5, two beds crop out in an otherwise $9.0 \mathrm{~m}$ covered interval. The age of the lower bed can only be considered Lower Llandovery based on the occurrence of Glyptograptus lacinosus Churkin and Carter. The overlying bed can be assigned to the atavus Zone based on the co-occurrence of Atavograptus atavus (Jones) and Glyptograptus? tenuis (Rickards). Above the covered interval a more diverse fauna can be found. The co-occurrence of Dimorphograptus erectus Elles and Wood, Glyptograptus ex gr. tamariscus (Nicholson) and Glyptograptus cf. G. lanpherei Churkin and Carter identify this sample as representing the acinaces-gregarius Zone. The occurrence of both Lagarograptus acinaces (Törnquist) and Coronograptus gregarius gregarius (Lapworth), among other taxa, in immediately overlying samples substantiates this.

At section 6, G. cf. G. lanpherei, Climacograptus innotatus n. ssp. and C. miserabilis Elles and Wood occur in a sample only $1.5 \mathrm{~m}$ above pacificus Zone samples. While these taxa, by themselves, could not allow accurate age assignment, the only other sample in which they co-occur is from the acinaces-gregarius Zone at section 5.

At section 7, fastigatus Zone samples are separated from beds yielding Monograptus spiralis (Geinitz) and other Upper Llandovery taxa by $3.0 \mathrm{~m}$ of unfossiliferous dolomites.

\section{Discussion of Faunas}

One of the noteworthy features of the Cape Phillips Ordovician graptolite fauna is its overall relatively low diversity and a total lack of observed dicellograptids. Jackson (1973) also noted the lack of dicellograptids in the Late Ordovician cratonic deposits of Canada pointing out that $\mathrm{Di}$ cellograptus appears to be restricted to the continental margin fold belts. Indeed, the deeper basinal sediments of northwestern Melville Island (Robson 1985) have yielded Dicellograptus in association with C. latus (Tozer and Thorsteinsson 1964; Lenz pers. comm. 1985).

The present diplograptid fauna is therefore considered to be a moderate to deep shelf fauna in which Dicellograptus is excluded by virtue of its apparent deep water or truly pelagic habitat. Erdtmann (1976, table 10) also compared the known latest Ordovician graptolite assemblages of Anticosti Island (shallow shelf) and of Scotland and Texas (pelagic). The Cape Phillips fauna appears to contain elements of both the shallow shelf fauna and the pelagic fauna and probably fits into the deep shelf, carbonate-shale belt of Erdtmann's scheme.

It is also noteworthy that diversity has generally increased from the base of the formation upward through the Ordovician, a trend coinciding with a general subsidence of the shelf during the Ashgill.

This subsidence appears to have been interrupted by a regression, probably associated with the latest Ordovician glaciation (Lenz 1976; Lenz and McCracken 1982). The effects of this regression are manifest as missing strata at some sections (due to erosion and/or nondeposition) and deposition of a massive carbonate unit at section 4 (possibly some missing strata as well).

Early Llandovery faunas also show low diversities and rather sporadic occurrence, possibly owing to deposition in relatively shallow, restricted conditions. It is not until the latest Early and Middle Llandovery that a more widespread, diverse graptolite fauna becomes established across the Cape Phillips belt (Melchin and Lenz 1984).

Acknowledgements. Special thanks are due to A. C. Lenz who provided valuable advice and assistance through all parts of this study. Field assistance was ably provided by E. C. Prosh, C. C. Ryley, S. W. White and A. C. Lenz.

Financial support was provided by a Natural Science and Engineering Research Council operating grant to A. C. Lenz and the Northern Research Group of the University of Western Ontario. Logistical support in the Arctic was provided by the Polar Continental Shelf Project.

\section{Systematic Paleontology}

All figured specimens are housed at the Geological Survey of Canada.

Order GRAPTOLOIDEA Lapworth, 1857

Family DIPLOGRAPTIDAE Lapworth, 1873

Genus Amplexograptus Elles and Wood, 1907

Amplexograptus aff. A. prominens Barrass, 1954 Plate 1, figures 1,2. 
Material. Numerous compressed specimens on a single bedding plane, all incomplete and most poorly preserved.

Occurrence. fastigatus Zone, Truro Island at $10.0 \mathrm{~m}$.

Description. Longest rhabdosome (incomplete) is $13 \mathrm{~mm}$. Widens from 0.8 to $0.9 \mathrm{~mm}$ at th $1^{1}$ to 1.1 to $1.2 \mathrm{~mm}$ at th $5^{1}$ reaching a maximum of 1.3 to $1.8 \mathrm{~mm}$ (average $1.5 \mathrm{~mm}$ ). Thecae number 14 to 16 in $10 \mathrm{~mm}$ throughout and are climacograptid in shape. Geniculum is extended into a flange or hood, supragenicular walls are straight and vertical. Thecal excavations occupy $1 / 4$ of total width proximally, $1 / 5$ distally. Apertural margins show lappets on distal fragments. Sicula $1.5 \mathrm{~mm}$ long bearing a virgella $0.3 \mathrm{~mm}$ long but no apertural spines. Mesial spines are likewise lacking on the first thecal pair.

Remarks. The apparent absence of proximal spines distinguishes this form from other contemporaneous species of $\mathrm{Am}$ plexograptus. However, since very few proximal ends are found in the present collection, and most of these are rather poorly preserved, the lack of proximal spines may be an artifact of preservation. Amplexograptus aff. A. prominens of Jackson (1973) is otherwise very similar (the overall narrower measurements found there were made on uncompressed specimens) and the two may be conspecific. Compressed specimens of $A$. prominens and A. elongatus (Barrass 1954) are wider than the present specimens and $A$. inuiti (Cox 1933) bears both sicular spines and a mesial spine on thecal ${ }^{1}$. Although Riva and Petryk (1981) recommended that the above taxa be grouped in the same species, the differences in proximal ornamentation is here considered sufficient justification for maintaining them as separate species.

Genus Climacograptus Hall, 1865

Climacograptus latus Elles and Wood, 1906

Plate 1, figures 3-8.

1906 Climacograptus latus Elles and Wood, p. 204-205, pl. 27 , figs. 3a-h, text-figs. 135a-d.

1982 Climacograptus latus Elles and Wood; Williams, p. 39-40, pl. 3, figs. 12-18 (see for further synonomy).

1982 Climacograptus latus Elles and Wood; Lenz and McCracken, fig. 3p,q.

Material. Hundreds of compressed and partially compressed specimens in various states of preservation from very good to poor.

Occurrence. fastigatus and pacificus zones, Truro Island at 12.0 to $29.0 \mathrm{~m}$. Twilight Creek at base to $3.5 \mathrm{~m}$, Trold Fiord at 38.5 to $43.0 \mathrm{~m}$, Huff Ridge at 89.5 to $93.0 \mathrm{~m}$ and Irene Bay at 59.0 to $62.5 \mathrm{~m}$.

Description. Largest thabdosome (complete) up to $30 \mathrm{~mm}$. Widens gradually from 0.8 to $1.0 \mathrm{~mm}$ at th $1^{1}$ to 1.2 to $1.3 \mathrm{~mm}$ at th5' to a maximum of 1.7 to $2.4 \mathrm{~mm}$ (average $2.0 \mathrm{~mm}$ ) reached by about the fifteenth thecal pair. Thecae number 7 in the first $5 \mathrm{~mm}$ and 11 to 12 in $10 \mathrm{~mm}$ distally. Thecae have straight supragenicular walls which commonly appear slightly inclined in compressed specimens due to differential widening. Apertural excavations occupy about $1 / 4$ of the rhabdosome width proximally and 1/5 to 1/6 distally. Proximal end bears a virgella and mesial spines on the first thecal pair which are each 0.5 to 0.7 $\mathrm{mm}$ long. Sicula is $1.8 \mathrm{~mm}$ long.

Remarks. This species is readily distinguishable from any other contemporary taxa. Climacograptus longispinus supernus is much narrower overall, especially in the proximal region. Although Orthograptus fastigatus has a similar rhabdosomal form, the thecal details distinguish them except in the most poorly preserved material where confusion may occur.

The present specimens are, on average, slightly narrower than the British material described by Williams (1982) and Elles and Wood (1906) and the distal thecal spacing is slightly wider. However, the proximal end development and overall rhabdosomal and thecal form which characterize this species are well illustrated by this material.

Climacograptus longispinus supernus Elles and Wood, 1906 Plate 1, figures 9-13.

1906 Climacograptus supernus Elles and Wood, p. 196-197, pl. 26, figs. 11a-d, text-fig. 127a-d.

1982 Climacograptus longispinus supernus Elles and Wood; Williams, p. 38-39, pl. 3, figs. 3-11, text-fig. 8a-o (see for further synonomy).

1982 Climacograptus supernus Elles and Wood; Lenz and McCracken, fig. 3k, 1.

1983 Climacograptus longispinus supernus Elles and Wood; Koren' and Sobolevskaya, p. 126-128, pl. XXXV, figs. 1-11, p. XXXVI, figs. 1-5, text-figs. $44,45$.

1983 Climacograptus longispinus supernus Elles and Wood; Wang et al., pl. 3, figs. 12, 13.

1984 Climacograptus supernus Elles and Wood; $\mathrm{Mu}$ and Lin, p. 57 , pl. 4 , figs. $4-6$.

Material. Numerous compressed specimens, very well to poorly preserved.

Occurrence. fastigatus and pacificus zones, Truro Island at 22.0 to $31.5 \mathrm{~m}$, Twilight Creek at base to $3.5 \mathrm{~m}$, Trold Fiord at 32.0 to $41.5 \mathrm{~m}$, Huff Ridge at 90.0 to $97.5 \mathrm{~m}$ and Irene Bay at 57.0 .

Description. Longest rhabdosome up to $18 \mathrm{~mm}$ long (complete) excluding spines. Widens gradually from 0.5 to $0.6 \mathrm{~mm}$ at th $1^{1}$ to 0.6 to $0.8 \mathrm{~mm}$ at th $5^{1}$ to a maximum of 1.0 to $1.5 \mathrm{~mm}$ by the fifteenth thecal pair; width is thereafter maintained. Thecae number 6 to 7 in the first $5 \mathrm{~mm}, 11$ to 13 in $10 \mathrm{~mm}$ distally. Thecae show a sharp geniculum and straight supragenicular walls, parallel to the rhabdosome length. Thecal excavations occupy about $1 / 3$ to $1 / 4$ total width. Proximal end bears a virgella up to $0.6 \mathrm{~mm}$ long and laterally projecting mesial spines on the first

Plate 1.

All figuires $\times 5$ unless otherwise indicated.

Fig. 1-2. Amplexograptus aff. A. prominens Barrass. (1) Truro Island-10.0 m, GSC78380. (2) Truro Island - $10.0 \mathrm{~m}, \mathrm{GSC78381.}$ Fig. 3-8. Climacograptus latus Elles and Wood. (3) Truro Island - $15.5 \mathrm{~m}, \mathrm{GSC} 78382$. (4) Irene Bay - 62.5 m, GSC78383. (5) Truro Island $-14.0 \mathrm{~m}$, GSC78384. (6) Truro Island $-14.0 \mathrm{~m}$, GSC78385. (7) Irene Bay $-62.5 \mathrm{~m}, \mathrm{GSC78386, \times 10.} \mathrm{(8)} \mathrm{Truro} \mathrm{Island} \mathrm{-} 14.0 \mathrm{~m}$, GSC78387.

Fig. 9-13. Climacograptus longispinus supernus Elles and Wood. (9) Irene Bay - $57.0 \mathrm{~m}$, GSC78388. (10) Irene Bay - $57.0 \mathrm{~m}$, GSC78389. (11) Truro Island $-30.5 \mathrm{~m}$, GSC78390. (12) Truro Island - $30.5 \mathrm{~m}, \mathrm{GSC78391}$. (13) Irene Bay $-57.0 \mathrm{~m}, \mathrm{GSC78392}$.

Fig. 14-15. Climacograptus sp. (14) Truro Island $-24.0 \mathrm{~m}$, GSC78393. (15) Truro Island - 24.0 m, GSC78394.

Fig. 16-20. Glyptograptus cf. G. lorrainensis (Ruedeman). (16) Trold Fiord - $40.5 \mathrm{~m}$, GSC78395. (17) Truro Island - 10.0 m, GSC78396. (18) Truro Island $-10.0 \mathrm{~m}$, GSC78397. (19) Truro Island $-10.0 \mathrm{~m}$, GSC78398, $\times 10$. (20) Truro Island - $10.0 \mathrm{~m}$, GSC78399. Fig. 21. Orthograptus aff. $O$. fastigatus Davies. Irene Bay $-57.0 \mathrm{~m}, \mathrm{GSC78400,} \times 2.5$. 


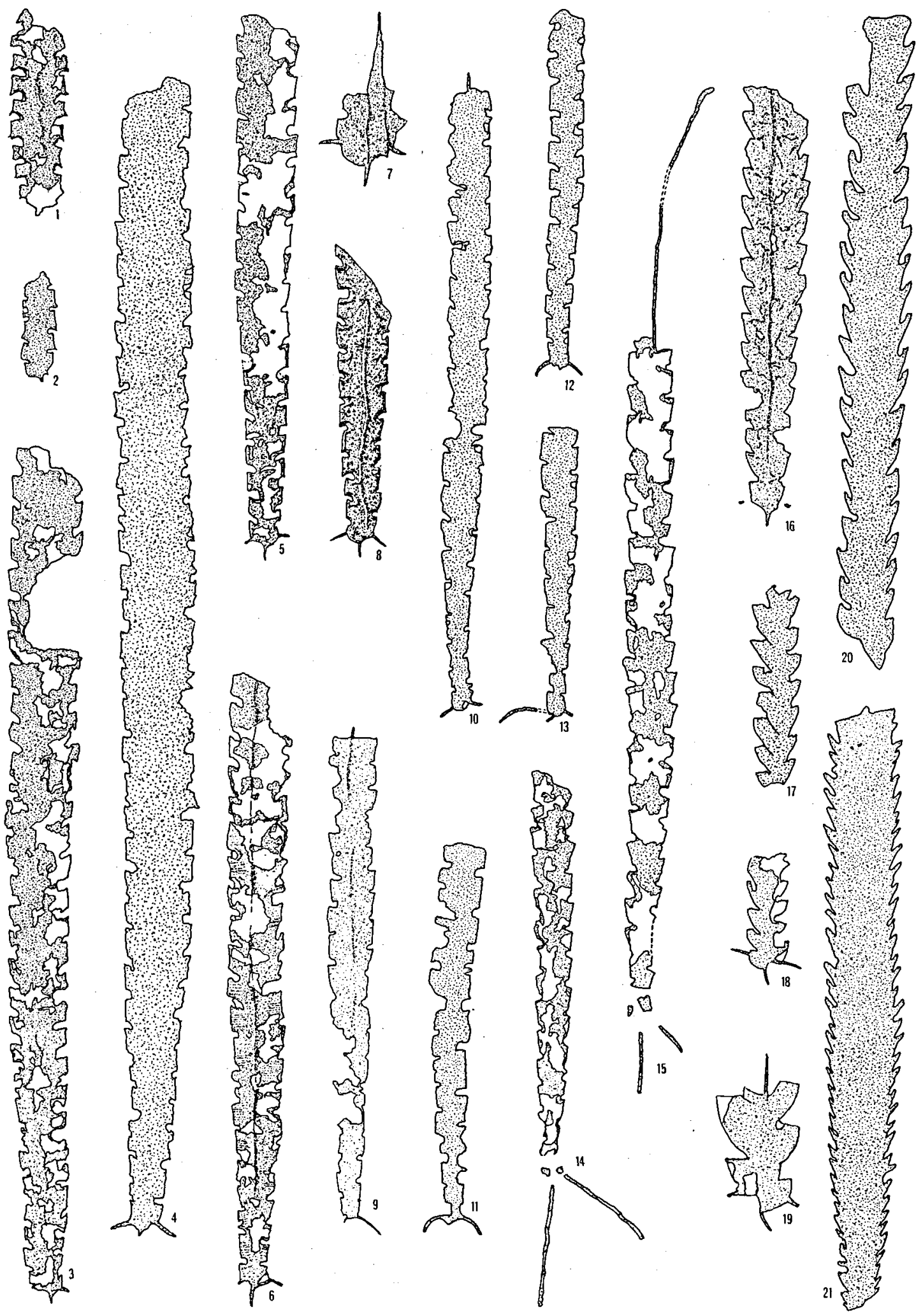


thecal pair up to a least $1.3 \mathrm{~mm}$. Membranes on proximal spines have not been observed in these specimens, nor have details of the sicula.

Remarks. Williams (1982) and Riva (1974) point out that the membrane on the proximal spines is only present on mature rhabdosomes. While many of the present specimens appear to be otherwise fully developed, it is possible that membrane development was somehow prevented, possibly owing to less favourable environmental conditions. Otherwise, the Cape Phillips material fits well within the previously reported range of variation for this distinctive taxon.

\section{Climacograptus sp.}

Plate 1, figures 14, 15.

Material. Fourteen compressed specimens, moderately to poorly preserved.

Occurrence. fastigatus Zone transition, Truro Island at $24.0 \mathrm{~m}$.

Description. Rhabdosome up to $20 \mathrm{~mm}$ long (complete) excluding virgella and virgula. Widens from $0.6 \mathrm{~mm}$ at th $1^{1}$ to 0.9 to $1.0 \mathrm{~mm}$ at th $5^{1}$ to a maximum of 1.0 to $1.3 \mathrm{~mm}$. Thecae number 10 to 12 in $10 \mathrm{~mm}$ throughout the length. Thecae show pronounced geniculum and supragenicular wall is generally inclined, but this may be due to differential spread of the apertures on compression. Thecal excavations semicircular and occupy $1 / 3$ to $1 / 4$ total width. Proximal end bears a virgella up to at least $4.0 \mathrm{~mm}$ long as well as (apparently) single mesial spines on the first thecal pair up to $3.0 \mathrm{~mm}$ long (the poor state of preservation of proximal portions prevents a more complete or accurate description). In addition, a free virgula extending up to $8.5 \mathrm{~mm}$ beyond the distal thecae is commonly present.

Remarks. The very slender rhabdosome combined with the relatively long basal spines and virgella distinguishes this taxon from most other known species of Climacograptus. Climacograptus hastatus Hall has a similar proximal ornamentation but is substantially wider. Climacograptus longispinus supernus is similar but lacks the long, prominent virgella and virgula and does not usually show the inclined supragenicular walls on compression. Climacograptus trifidus spectabilis Koren' and Sobolevskaya is very similar but apparently lacks the inclined supragenicular walls and the long virgula. Poor preservation of the present specimens, however, prevents positive identification.

Genus Glyptograptus Lapworth, 1873

Glyptograptus cf. G. lorrainensis (Ruedemann, 1925)

Plate 1, figures 16-20.

Material. Numerous compressed specimens, moderately to poorly preserved.

Occurrence. fastigatus Zone, Truro Island to 9.0, 10.0 and 20.0 $\mathrm{m}$, and Trold Fiord at $40.5 \mathrm{~m}$.
Description. The longest rhabdosome is $19 \mathrm{~mm}$ (incomplete). Widens from 0.75 to $0.9 \mathrm{~mm}$ at th $1^{1}$ to 1.1 to $1.2 \mathrm{~mm}$ at th $5^{1}$ to a maximum of 1.5 to $1.8 \mathrm{~mm}$ although a few specimens up to 2.0 $\mathrm{mm}$ have been found. Thecae number 7 to 7.5 in the first $5 \mathrm{~mm}$ and 12 to 13 in $10 \mathrm{~mm}$ distally. Thecae show a pronounced glyptograptid profile and th $1^{1}$ carries a mesial spine. Lappets are evident on apertural margins, especially on distal thecae. Sicula is $1.5 \mathrm{~mm}$ long with a $0.3 \mathrm{~mm}$ virgella and paired apertural spines.

Remarks. This form is probably conspecific with Glyptograptus cf. G. lorrainensis as described by Jackson (1973). The only difference is that the present specimens show a greater maximum width, but this is attributed to the greater length of the present specimens. None of the specimens described by Jackson was greater than $4 \mathrm{~mm}$ long. Glyptograptus lorrainensis is slightly narrower overall and apparently lacks apertural lappets (Walters 1977). Glyptograptus hudsoni Jackson, 1971 is wider, particularly at the proximal end, and lacks apertural lappets.

Genus Orthograptus Lapworth, 1873

Orthograptus ex gr. amplexicaulis (Hall, 1847)

Plate 2, figures 11, 13, 14.

Material. Twenty compressed specimens, moderately to poorly preserved.

Occurrence. fastigatus and pacificus zones, Truro Island at 12.0 and $29.0 \mathrm{~m}$ and Twilight Creek at $3.0 \mathrm{~m}$.

Description. Longest rhabdosome is $37 \mathrm{~mm}$ (incomplete). Widens very gradually from $1.2 \mathrm{~mm}$ at th $1^{1}$ to a maximum of 3.0 to $3.5 \mathrm{~mm}$ which is thereafter maintained.

Thecae number 7 in the first $5 \mathrm{~mm}$ and 10 to 12 in $10 \mathrm{~mm}$ distally. Thecal walls straight to slightly sigmoidal, inclined at 40 to $60^{\circ}$ to rhabdosome axis, with everted apertures.

Remarks. Williams (1982) points out that much needed revision on the $O$. amplexicaulis group is under way. Until such time as this work is published, more specific assignment of this rather poorly preserved material is considered unjustified. Comparison can be made with $O$. abbreviatus (Elles and Wood 1907) which is narrower than the present specimens and also gets narrower distally once its maximum width is achieved. This is not observed in the Cape Phillips material.

Orthograptus fastigatus Davies, 1929

Plate 2, figures 1-7, 9.

1929 Orthograptus fastigatus Davies, p. 4, text-figs. 3-5,

1970 Diplograptus fastigatus (Davies); Toghill, p. 21, pl. 14, figs. 1-9.

1982 Orthograptus fastigatus Davies; Williams, pp. 40-41, pl. 4, figs. 1-6.

1984 Orthograptus fastigatus Davies; Mu and Lin, p. 60, pl. 5, figs. $11,12$.

Plate 2.

All figures $\times 5$ unless otherwise indicated. Fig. 1-7, 9. Orthograptus fastigatus Davies. (1) Truro Island $-7.2 \mathrm{~m}, \mathrm{GSC78401,} \times 2.5$. (2) Irene Bay $-58.0 \mathrm{~m}$. GSC78402. (3) Truro Island $-7.2 \mathrm{~m}$, GSC78403, $\times 10$. (4) Truro Island $-14.0 \mathrm{~m}$, GSC78404. (5) Irene Bay - 58.0 $\mathrm{m}, \mathrm{GSC7} 8405, \times 10$. (6) Irene Bay $-58.0 \mathrm{~m}, \mathrm{GSC78406}$. (7) Truro Island $-7.2 \mathrm{~m}, \mathrm{GSC} 78407$. (9) Irene Bay $-58.0 \mathrm{~m}, \mathrm{GSC78408}$

Fig. 8. 10, 12. Orthograptus thorsteinssoni n. sp. (8) Holotype, Truro Island $-12.0 \mathrm{~m}, \mathrm{GSC} 78409, \times 2.5$. (10) Paratype, Truro Island $12.0 \mathrm{~m}$, GSC78410, $\times 2.5$. (12) Paratype, Truro Island $-12.0 \mathrm{~m}, \mathrm{GSC78411.}$

Fig. 11, 13, 14. Orthograptus ex gr. amplexicaulis (Hall). (11) Truro Island - $12.0 \mathrm{~m}$, GSC78412. (13) Truro Island - $29.0 \mathrm{~m}$, GSC 78413. (14) Truro Island $-12.0 \mathrm{~m}$, GSC78414.

Fig. 15-17. Paraorthograptus pacificus (Ruedeman). (15) Truro Island - $30.5 \mathrm{~m}, \mathrm{GSC78415}$. (16) Truro Island - $30.5 \mathrm{~m}, \mathrm{GSC78416.}$ (17) Huff Ridge $-93.0 \mathrm{~m}$, GSC78417. 


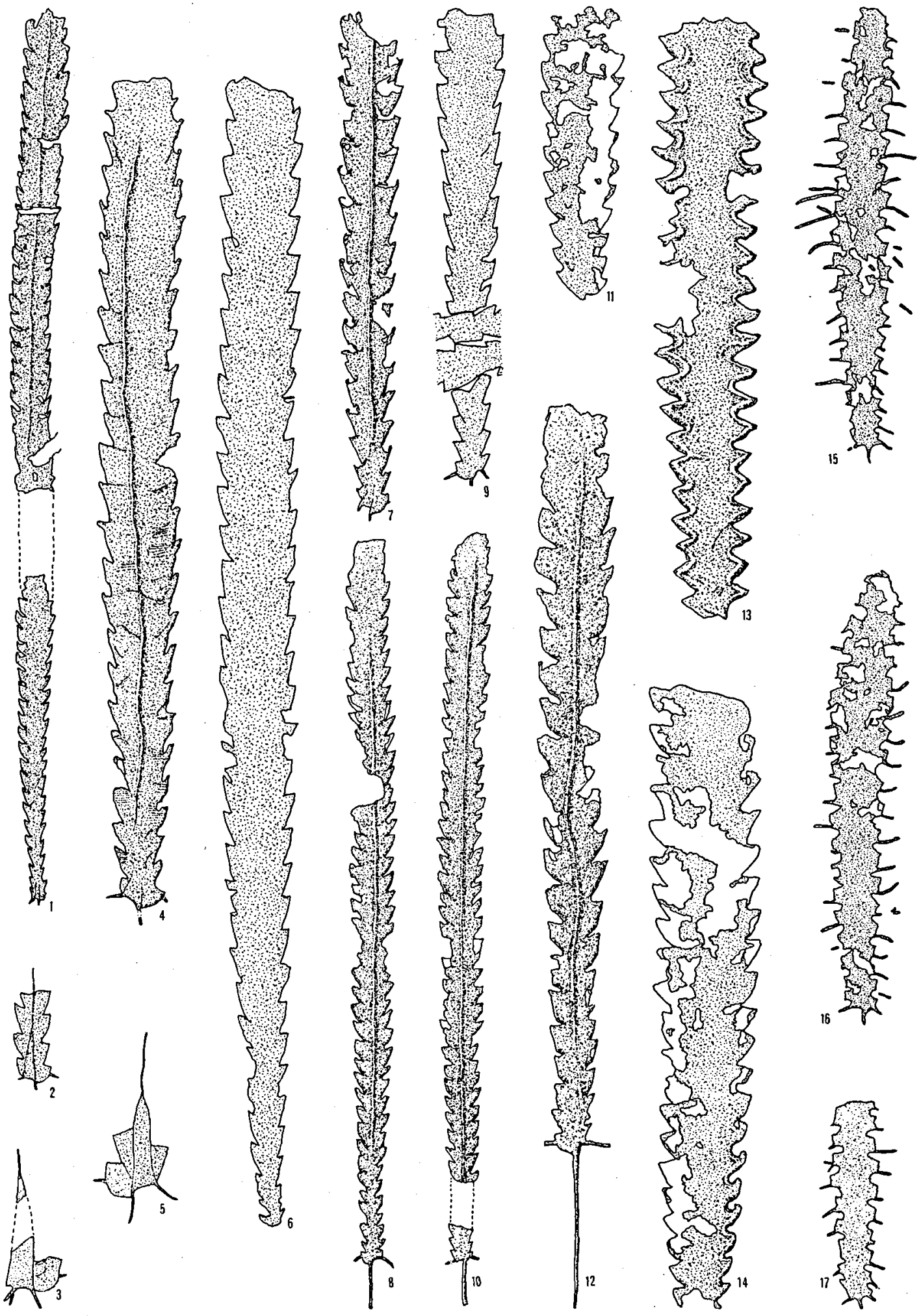


Material. Hundreds of compressed specimens, very well to poorly preserved.

Occurrence. fastigatus Zone, Snowblind Creek at $25.0 \mathrm{~m}$, Rookery Creek at $4.5 \mathrm{~m}$, Truro Island at 8.0 to 20.0 , Twilight Creek at base to $3.5 \mathrm{~m}$, Trold Fiord at 20.0 to $41.5 \mathrm{~m}$, Huff Ridge at 48.0 to $78.5 \mathrm{~m}$ and Irene Bay at 57.0 to $62.5 \mathrm{~m}$.

Description. Longest rhabdosome is $53 \mathrm{~mm}$ (complete). Widens very gradually from 0.7 to $1.1 \mathrm{~mm}$ (averange $0.9 \mathrm{~mm}$ ) at th $1^{1}$ to .9 to $1.7 \mathrm{~mm}$ (average $1.2 \mathrm{~mm}$ ) at th $5^{1}$ to a maximum of 1.8 to $3.2 \mathrm{~mm}$ (average $2.3 \mathrm{~mm}$ ) which is reached between the fifteenth and twentyfifth thecal pair. Thecae number 6 to 8 in the first $5 \mathrm{~mm}$ and 10 to 14 in $10 \mathrm{~mm}$ distally. Thecae are straight to slightly sigmoidally curved, especially in the proximal region. Thecal apertures introverted and straight. Sicula 1.4 to $1.6 \mathrm{~mm}$ long and bears a virgella and a pair of apertural spines up to $1.3 \mathrm{~mm}$ long (generally less than $0.5 \mathrm{~mm}$ ). Theca $1^{1}$ bears a mesial spine of similar length.

Remarks. The present material shows a wider range of morphologic variation than the British material, particularly in the maximum width. In addition, the thecal spacing is, on average, slightly wider, although there is considerable overlap with the British specimens. Davies (1929) and Williams (1982) reported the presence of mesial spines on both of the first thecae. The presence of many well preserved proximal ends in the present collections, however, shows that theca $1^{2}$ lacks a mesial spine, but the sicula bears a pair of apertural spines although only one is visible in the vast majority of specimens. This may also be the case for the British material.

The very gradual tapering of the proximal end together with the orthograptid thecae with introverted apertures distinguishes this taxon from all others except for $O$. thorsteinssoni which has much longer, more prominent basal spines.

Orthograptus aff. O. fastigatus Davies, 1929

Plate 1, figure 21 .

Material. One compressed specimen well preserved but lacking proximal end.

Occurrence. fastigatus Zone, Irene Bay at $57.0 \mathrm{~m}$.

Description. Rhabdosome $37 \mathrm{~mm}$ long (incomplete). Widens from $2.2 \mathrm{~mm}$ at the first preserved thecal pair (near proximal end) to a maximum of $4.2 \mathrm{~mm}$ at the twentieth preserved thecal pair which is thereafter maintained. Thecae number 10 in 10 $\mathrm{mm}$, are orthograptid in profile and are inclined at a relatively Jow angle to the rhabdosome. Thecal apertures are straight and introverted. Proximal portions are not preserved.

Remarks. This taxon closely resembles $O$. fastigatus except for its greater width. It also resembles wider members of the $O$. calcaratus group although the proximal end appears to taper more gently. It most closely resembles $O$. maximus, which was originally (and probably correctly) considered a variety of $O$. fastigatus. The present specimens are slightly wider with a slightly closer thecal spacing. In the absence of preserved proximal parts, however, it is not possible to make a positive identification.

Orthograptus thorsteinssoni $\mathrm{n} . \mathrm{sp}$.

Plate 2, figures 8, 10, 12 .

Material. About twenty compressed specimens, very well to poorly preserved. Holotype is GSC78409.

Occurrence. fastigatus Zone, Rookery Creek at $4.5 \mathrm{~m}$, Truro Island at $12.0 \mathrm{~m}$ (type locality) and Twilight Creek at base.
Diagnosis. Large rhabdosome widening gradually from 0.9 to $1.1 \mathrm{~mm}$ at th $1^{1}$ to a maximum of 2.3 to $2.8 \mathrm{~mm}$ at the twentieth thecal pair. Thecal spacing is 9.5 to 10.5 in $10 \mathrm{~mm}$. Proximal end bears a long virgella up to at least $5.0 \mathrm{~mm}$ as well as a pair of proximal spines up to $2.0 \mathrm{~mm}$ long.

Description. Longest rhabdosome is $46 \mathrm{~mm}$ (complete) excluding virgella. Widens very gradually from 0.9 to $1.1 \mathrm{~mm}$ at th $1^{1}$ to 1.3 to 1.5 at th $5^{1}$ to a maximum of 2.3 to $2.8 \mathrm{~mm}$ (average 2.5 $\mathrm{mm}$ ) attained near the twentieth thecal pair. Thecae number 6 in the first $5 \mathrm{~mm}$ and 9.5 to $10.5 \mathrm{in} 10 \mathrm{~mm}$ distally. Thecae are straight to slightly sigmoidally curved, especially in proximal region, with 1/3 overlap. Thecal apertures are introverted. Sicula is not visible but shows a strongly notched aperture with a very conspicuous virgella up to at least $5.0 \mathrm{~mm}$ long. In addition, a pair of proximal spines are present up to $2.0 \mathrm{~mm}$ in length.

Remarks. This new species most closely resembles Orthograptus fastigatus but differs from it in the very long, prominent virgella and proximal spines. The very gently tapering proximal end distinguishes it from other members of the $O$. calcaratus group of which it is probably a late member. Although many of the thecae appear to be glyptograptid, especially in the proximal region, the best preserved material shows that the thecae are indeed orthograptid in nature.

The spine arising from th $1^{1}$ is clearly a mesial spine but is not clear form the present material if the opposite spine arises from th $1^{2}$ or the sicular aperture. The possibility exists that it is one of a pair of sicular apertural spines as in $O$. fastigatus.

Genus Paraorthograptus $\mathrm{Mu}$ et al., 1974

Paraorthograptus pacificus (Ruedemann, 1947)

Plate 2, figures 15-17.

1947 Climacograptus innotatus var. pacificus Ruedemann, p. 429, pl. 73, fig. 29.

1982 Paraorthograptus pacificus (Ruedemann); Williams, p. 42, text-fig. 10d-i (see for further synonomy).

1982 Pacificograptus pacificus (Ruedemann); Lenz and McCracken, fig. $3 \mathrm{~g}, \mathrm{o}$.

1983 Paraorthograptus pacificus pacificus (Ruedemann); Koren' and Sobolevskaya, p. 154-156, pl. XLV, figs. 3-5, pl. XLVI, figs. 1-3, text-figs. $59,60 \mathrm{a}$.

1983 Paraorthograptus pacificus kimi (Koren'); Koren' and Sobolevskaya, p. 156-157, pl. XLVI, figs. $4-7$, pl. XLVII, figs. 1-3.

1983 Paraorthograptus minor Wang (in Wang, et al.), p. 142143, pl. 6, figs. 1,6 .

?1983 Paraorthograptus fenxiangensis Wang (in Wang, et al.), p. 143 , pl. 6 , fig. 8 .

1984 Paraorthograptus typicus $\mathrm{Mu} ; \mathrm{Mu}$ and Lin, p. 61-62, pl. 6, figs. 3-5.

?1984 Paraorthograptus uniformis $\mathrm{Mu}$ and $\mathrm{Li} ; \mathrm{Mu}$ and $\mathrm{Lin}, \mathrm{p}$. 62 , pl. 4 , fig. 7 ; pl. 6 , figs. 7,8 .

Material. About twenty specimens, well to poorly preserved.

Occurrence. pacificus Zone, Truro Island at 26.2 to $31.5 \mathrm{~m}$ and Huff Ridge at 93.0 to $97.5 \mathrm{~m}$.

Description. Longest rhabdosome is $15 \mathrm{~mm}$ long. Widens from 0.7 to $1.0 \mathrm{~mm}$ (average $0.8 \mathrm{~mm}$ ) at th $\mathrm{th}^{1}$ to 1.0 to $1.5 \mathrm{~mm}$ (average $1.2 \mathrm{~mm}$ ) at th $5^{\mathrm{i}}$ to a maximum of 1.3 to $1,9 \mathrm{~mm}$ (average 1.7 to $1.8 \mathrm{~mm}$ ) achieved by the tenth to fifteenth thecal pair. Thecae number 8 in the first $5 \mathrm{~mm}$ and 14 in $10 \mathrm{~mm}$ distally. Sharp geniculum on all thecae bears paired spines up to $0.6 \mathrm{~mm}$ long on proximal thecae and up to $1.0 \mathrm{~mm}$ distally.

Supragenicular wall short, straight and slightly inclined. Apertures gently everted, excavations shallow, occupying $1 / 5$ to 
$1 / 6$ total widh. Sicula obscured, bears virgella up to $0.6 \mathrm{~mm}$ long.

Remarks. While several different species of Paraorthograptus have been identified from various parts of the world, Williams (1982) suggests that the criteria on which they have been separated does not merit the distinction of separate taxa. He recommends that they should be considered synonymous until an integrated study has been carried out on this genus. That suggestion has been followed here. Of the previously described taxa, the present material closely matches $P$. typicus and $P$. pacificus kimi in the observed dimensions. Paraorthograptus minor appears to represent juvenile forms of this species and most of the Huff Ridge specimens are equally small.

\section{Dansk sammendrag}

Graptolitter af asgillian alder er blevet indsamlet fra syv blotninger i Cape Phillips Formationen over det meste af formationens forekomstområde. Den aldste graptolitzone er karakteriseret af Orthograptus fastigatus. Den korreleres med $\mathrm{Di}$ cellograptus ornatus zonen i de nordlige canadiske cordillera og med Dicellograptus complexus underzonen i Dicellograptus anceps zonen i Storbritannien på trods af, at der ikke er fundet nogen dicellograptider i profilerne. Den overliggende zone med Paraorthograptus pacificus er velkendt over det meste af verden.

Graptolitter fra Climacograptus extraordinarius og Glyptograptus persculptus zonerne synes at mangle helt i den omtalte formation. Det tilskrives den sene ordovisiske nedisning som medførte regression og submarin erision $i$ mange af verdens områder.

Den forste siluriske zone der kan genkendes varierer fra blotning til blotning pga. begravede eller fossiltomme intervaller evt. med hiati af vekslende lengde. Parakidograptus acuminatus zonen er blevet fundet på kun en lokalitet. I andre blotninger er Atavograptus atavus, lagarograptus acinacex-Coronograptus gregarius, Monograptus convolutus eller Monograptus spiralis (s.l.) zonerne fundet som de yngste siluriske faunaer.

Den lave diversitet $i$ asgillian og nederste llandovery delen af lagserien sammen med fravaret af dicellograptider tolkes som indicium på lavere vandstand.

\section{References}

Barrass, R. 1954: Graptolites from Anticosti Island. Quart. J. Geol. Soc. London 110, 55-74.

Bergström, S. M. \& Mitchell, C. E. 1986: The graptolite correlation of the North American Upper Ordovician Standard: Lethaia 19, 247-266.

Chen, X. \& Lenz, A. C. 1984: Correlation of Ashgill graptolite faunas of central China and arctic Canada, with a description of Diceratograptus cf. mirus Mu from Canada. In: Nanjing Inst. Geol. Palaeont. (editors) Stratigraphy and palaeontology of systemic boundaries in China, Ordovician-Silurian boundary, 247-258.

Churkin, M. Jr. \& Carter, C. 1970: Early Silurian graptolites from southeastern Alaska and their correlation with graptolitic sequences in North America and the Arctic. $U$. S. Geol. Surv. Prof. Pap. 653, 51 pp.

Cox, I. 1933: On Climacograptus inuiti sp. nov. and its development: Geol. Mag. 70, 1-19.

Davies, K. A. 1929: Notes on the graptolite faunas of the Upper Ordovician and Lower Silurian. Geol. Mag. 66, 1-27.
Elles, G. L. \& Wood, E. M. R. 1901-1918: A monograph of British Graptolites. Monogr. palaeontogr. Soc. London ICLXXI, 1-539.

Erdtmann, B.-D. 1976: Ecostratigraphy of Ordovician graptoloids. In: Bassett, M. G. (editor) The Ordovician System: proceedings of a Palaeontological Association symposium, Birmingham, September 1975, 621-643.

Jackson, D. E. 1971: Development of Glyptograptus hudsoni sp. nov. from Southhampton Island, North West Territories, Canada. Palaeontology 14, 478-486.

Jackson, D. E. 1973: Amplexograptus and Glyptograptus isolated from Ordovician limestones in Manitoba. Geol. Surv. Can. Bul. 222, 1-8.

Jackson, D. E., Lenz, A. C. \& Pedder, A. E. H. 1978: Late Silurian and Early Devonian graptolite, brachiopod and coral faunas from northwestern and arctic Canada. Geol. Assoc. Can. Spec. Pap. 17, 159 pp.

Kerr, J. W. 1974: Geology of Bathurst Island group and Byam Martin Island, arctic Canada (Operation Bathurst Island). Geol. Surv. Can. Mem. 378, 152 pp.

Kerr, J. W. 1976: Stratigraphy of central and eastern Ellesmere Island, arctic Canada, part III. Upper Ordovician, Silurian and Devonian. Geol. Surv, Can. Bull. 260, 55 pp.

Koren', T. N. \& Sobolevskaya, R. F. 1983: Graptolites. In: Sokolov, B. S., Koren', T. N. \& Nikitin, I. F. (editors) The Ordovician and Silurian boundary in the Northeast of the U.S.S.R. Leningrad, (Nauka), 97-160 (in Russian).

Lenz, A. C. 1974a: Evolution in Monograptus priodon. Lethaia $7,265-272$.

Lenz, A. C. 1974b: A membrane-bearing Cyrtograptus and an interpretation of the hydrodynamics of cyrtograptids. In: Rickards, R. B., Jackson, D. E. \& Hughes, C. P. (editors) Graptolite studies in honour of O. M. B. Bulman. Spec. Pap. Palaeont. 13, 205-214.

Lenz, A. C. 1976: Late Ordovician-Early Silurian glaciation and the Ordovician-Silurian boundary in the northern $\mathrm{Ca}$ nadian Cordillera. Geol. 3, 313-317.

Lenz, A. C. 1978: Llandoverian and Wenlockian Cyrtograptus and some other Wenlockian graptolites from northern and arctic Canada. Geobios 11, 623-653.

Lenz, A. C. \& McCracken, A. D. 1982: The Ordovician-Silurian boundary, northern Canadian Cordillera: graptolite and conodont correlation. Can. J. Earth Sci. 19, 13081322.

Ludvigsen, R. 1979: The Ordovician trilobite Pseudogygites Kobayashi in eastern and arctic North America. Roy. Ont. Mus. Life Sci. Cont. 120, 41 pp.

Mayr, U. 1974: Lithologies and depositional environments of the Allen Bay-Read Bay Formations (Ordovician-Silurian) on Svendsen Peninsula, central Ellesmere Island. In: Aitken, J. D. \& Glass, D. F. (editors) Proceedings of the symposium on the geology of the Canadian Arctic. Geol. Assoc. Can. - Can. Soc. Petrol. Geol., 143-157.

Mayr, U. 1980: Stratigraphy and correlation of Lower Paleozoic formations, subsurface of Bathurst Island and adjacent smaller islands, Canadian Arctic Archipelago Geol. Surv. Can. Bull. 306, 52 pp.

Melchin, M. J. \& Lenz, A. C. 1984: Upper Ordovician to Lower Silurian graptolites: Cape Phillips. Formation, central Canadian Arctic Islands. Geol. Assoc. Can. - Min. Assoc. Can. Joint Ann. Meeting, May, 1984, Program with Abstracts, p. 88 (abst.)

Mirza, K. 1976: Late Ordovician to Late Silurian Stratigraphy and Conodont Biostratigraphy of the eastern Canadian Arctic Islands. Unpublished M. Sc. Thesis, University of Waterloo, Waterloo, Canada.

Mu, E.-Z. \& Lin, Y.-K. 1984: Graptolites from the Ordovician-Silurian boundary sections in the Yichang area, W. Hubei. In: Nanjing Inst. Geol. Palaeont. (editors) Strat- 
igraphy and palaeontology of systemic boundaries in China, Ordovician-Silurian boundary, 45-82.

Read, J. F. 1982: Carbonate platforms of passive (extensional) continental margins: types, characteristics and evolution. Tectonophysics 81, 195-212.

Riva, J. 1969: Middle and Upper Ordovician graptolite faunas of St. Lawrence Lowlands of Quebec, and of Anticosti Island. In: North Atlantic geology and continental drift, Amer. Assoc. Petrol. Geol. Mem. 12, 513-556.

Riva, J. 1974: Late Ordovician spinose climacograptids from the Pacific and Atlantic faunal provinces. In: Rickards R. B., Jackson, D. E. \& Hughes, C. P. (editors) Graptolite studies in honour of O. M. B. Bulman. Spec. Pap. Palaeont. 13, 141-147.

Riva, J. \& Petryk, A. A. 1981: Graptolites from the Upper Ordovician and Lower Silurian of Anticosti Island and the position of the Ordovician-Silurian Boundary. In: Lespérance, P. J. (editor) Subcommission on Silurian Stratigraphy, Ordovician-Silurian boundary Working Group. Field Meeting, Anticosti-Gaspé Québec 1981, V. II: Stratigraphy and Paleontology, 159-164.

Robson, M. J. 1985: Lower Paleozoic stratigraphy of northwestern Melville Island, District of Franklin. In: Current Research, Pt. B, Geol. Surv. Can. Pap. 85-1b, 281-284.

Ruedemann, R. 1947: Graptolites of North America. Mem. Geol. Soc. Amer. 19, 652 pp.

Sodero, D. E. \& Hobson, J. P. 1979: Depositional facies of Lower Paleozoic Allen Bay carbonate rocks and contiguous shelf and basin strata, Cornwallis and Griffith islands, Northwest Territories, Canada. A.A.P.G. Bull. 63, 1059-1091.

Sweet, W. C. \& Miller, A. K. 1957: Ordovician cephalopods from Cornwallis and Little Cornwallis islands, District of Franklin, Northwest Territories. Geol. Surv. Can. Bull. 38, $86 \mathrm{pp}$.

Thorsteinsson, R. 1955: The mode of cladial generation in Cyrtograptus. Geol. Mag. 92, 37-49.

Thorsteinsson, R. 1958: Cornwallis and Little Cornwallis is- lands, District of Franklin, Northwest Territories. Geol. Surv. Can. Mem. 294, 134 pp.

Thorsteinsson, R. \& Fortier, Y. O. 1954: Report of progress on the geology of Cornwallis Island, Arctic Archipelago, Northwest Territories. Geol. Surv. Can. Pap. 53-24, 25 pp.

Thorsteinsson, R. \& Glenister, B. F. 1963: Driftwood Bay. In: Fortier, Y. O. et al. (editors) Geology of the north-central part of the Arctic Archipelago, Northwest Territories (Operation Franklin). Geol. Surv. Can. Mem. 320, 585-596.

Toghill, P. 1970: Highest Ordovician (Hartfell Shales) graptolite faunas from the Moffat area, South Scotland. Bull. Brit. Mus. natural Hist. (Geol.) 19, 1-26.

Tozer, E. T. 1963: Trold Fiord. In: Fortier, Y. O. et al. (editors) Geology of the north-central part of the Arctic Archipelago, Northwest Territories (Operation Franklin). Geol. Surv. Can. Mem. 320, 370-380.

Tozer, E. T. \& Thorsteinsson, R. 1964: Western Queen Elizabeth Islands, Arctic Archipelago. Geol. Surv. Can. Mem. 332, $242 \mathrm{pp}$.

Trettin, H. P. 1979: Middle Ordovician to Lower Devonian deep-water succession at southeastern margin of Hazen Trough, Cañon Fiord, Ellesmere Island. Geol. Surv. Can. Bull. 272, $84 \mathrm{pp}$.

Troelsen, J. C. 1950: Contributions to the geology of northwest Greenland, Ellesmere Island and Axel Heiberg Island. Medd. om Grønland, 149 (7), 85 pp.

Walters, M. 1977: Middle and Upper Ordovician graptolites from the St. Lawrence Lowlands, Quebec, Canada. Can. J. Earth Sci. 14, 932-952.

Wang, X., Zeng, Q, Zhou, T., Ni, S., Xu, G., Sun, Q., Li, Z., Xiang, I. \& Lai, C. 1983: Latest Ordovician and earliest Silurian faunas from the eastern Yangtze Gorges, China with comments on Ordovician-Silurian boundary. Bull. Yichang Inst. Geol. Mineral. Res., Chinese Acad. Geol. Sci. 6, 129-155.

Williams, S. H. 1982: The late Ordovician graptolite fauna of the Anceps Bands at Dob's Linn, southern Scotland. Geol. et Palaeont: 16, 29-56. 